\title{
Constructing hedonic art price indexes for the Polish painting market. Using direct and indirect approaches
}

\author{
Witkowska, Dorota \\ Kompa, Krzysztof
}

- Received: 3 august 2014

- ACCEPTED: 17 NOVEMBER 2014

\begin{abstract}
Artworks can be considered either as an aesthetic attraction or as an investment opportunity. Investing in art has been treated as an alternative investment asset used to diversify the portfolio or as collateral, especially during times of uncertainty in financial markets. It should, however, be noted that certain specific features of artworks mean that investment in art cannot be compared to investment in conventional assets. In order to decide whether art is a good investment, it is necessary to estimate the expected returns that might be generated by such an investment. This requires the development of an art price index. The aim of this paper is to examine artworks as investment assets and to construct a price index of paintings made up of 17 Polish artists whose artworks were most often traded at auctions held in Poland between 2007 and 2013. In our research, we employ data on 1710 objects and apply the hedonic index methodology to estimate returns from the paintings market.
\end{abstract}

\section{Keywords:}

Art market, Hedonic price index, Investment, Alternative investment asset, Financial markets.

JEL classification:

Z11, C43, C51, G11

Witkowska, D. Department of Finance and Strategic Management, University of Lodz, 22/25 Matejki St., 90-237 Lodz, Poland. C)+48516044 800,+48 4263552 25. Fax:+48 4263553 05. E-mail: dorota.witkowska@uni.lodz.pl

Kompa, K. Department of Econometrics and Statistics, Warsaw University of Life Sciences, 166 Nowoursynowska St., 02-787 Warsaw, Poland. P+48 509936 736, +48 225937 25I.Fax:+48 2259372 22. E-mail: krzysztof_kompa@sggw.pl 


\title{
Índices de precios hedónicos para el mercado del arte polaco. Aplicación de los enfoques directo e indirecto
}

\author{
Witkowska, Dorota \\ Kompa, Krzysztof
}

\section{Resumen}

Las obras de arte pueden ser consideradas tanto desde la perspectiva de su atractivo estético como desde el punto de vista de una oportunidad de inversión. La inversión en arte ha sido considerada como una alternativa de inversión con vistas a la diversificación de la cartera, o como un colateral, especialmente en situaciones de incertidumbre en los mercados financieros. Sin embargo, se debe poner de manifiesto que las características específicas de las obras de arte implica la imposibilidad de comparación entre la inversión en arte y la inversión en activos convencionales. Para dar respuesta a la pregunta relativa a si la inversión en arte es o no una inversión acertada, es necesaria la estimación de sus rendimientos esperados, lo cual implica la elaboración del correspondiente índice de precios hedónicos.

El objetivo de este artículo es el análisis de las obras de arte como activos de inversión y la elaboración del índice de precios de las pinturas de 17 artistas polacos, precios que se negociaron en la mayoría de las ocasiones en subastas realizadas en Polonia en el periodo 2007-2013. A partir de los precios de 1.710 pinturas, se aplica la metodología de índices hedónicos para la estimación de los rendimientos de dicho mercado.

\section{Palabras clave:}

Mercado del arte, índice de precios hedónicos, inversión, activo de inversión alternativo, mercados financieros. 


\section{Introduction}

Art is a finite commodity and the value of suitable purchases can increase significantly over time. The history of investment in art dates back to the 17th century, when the rich and famous old European families followed the strategy of capital formation: onethird was invested in stocks, bonds and other securities, one-third in real estate and one-third in arts, precious metals, gemstones, and so on. (Makseliene, 2007). The first art boom occurred in the Netherlands in the 17th century, and even a hundred years later Dutch paintings were the most expensive in the world. The "name buying" principle was established in the 18th century, and continues to be relevant today (Jurevičien and Savičenko, 2012). These days, collecting art is a recognized investment strategy and fine art is a genuine alternative asset class with a proven track record ${ }^{1}$. Art tends not to fluctuate as much as the stock market and art investment portfolios can provide strong income streams in addition to potential long-term capital growth. It should, however, be noted that certain specific features of artworks mean that investment in art cannot be compared to investment in conventional assets, since certain art genres outperform others for a number of reasons. Art can be an unpredictable investment in which returns may be heavily influenced by not only a number of macro-factors, such as economic growth and inflation, but also micro-factors unique to the market, such as global interest in certain genres and changes in trends, tastes and culture.

It is also worth mentioning that, unlike traditional asset classes such as stocks or bonds, there is very little transparency associated with art trading. This is due to the fact that private transactions make up a large segment of the market, making it difficult for outsiders to gain insight. This situation also makes it challenging to estimate the size of the market and consequently different sources attribute a variety of values to the global art market. According to The European Fine Art Foundation (TEFAF), the size of the global art market is roughly US\$56 billion, which reflects public auction data and an estimate of art gallery and private art dealer sales during $2012^{2}$.

In order to analyze the financial performance of art investments, it is necessary to estimate the expected returns that may be generated by such an investment. This requires the development of an art price index. There are two main approaches for producing art price indexes: analyzing repeat sales of the same object at auction; and developing a hedonistic model, which takes into account characteristics and qualities of the individual works. Numerous studies have been conducted to measure the historical returns

\footnotetext{
${ }^{1}$ There is growing literature on the relation of arts and investment:Anderson (1974), Stein (1977), Frey and Eichenberger (1995), Frey and Pommerehne (1988), (1989a), Pesando (1993), Mei and Moses (2002),Worthington and Higgs (2003), (2004), Edwards (2004), Campbell (2004), (2008), Kraeussl and van Elsland (2008), Higgs (2012), Hsieh et al. (2010), Kraeussl and Wiehenkamp (2012), and Frey and Cueni (2013) to mention a few.

${ }^{2}$ Sommer (2013), quoted after www.tefaf.com.
} 
of art investments ${ }^{3}$. Regardless of how calculation methodologies, sample data and time periods vary, most studies show that over long periods of time art prices have trended upwards, kept pace with inflation and, in several studies, have outperformed more traditional asset classes such as equities and bonds over certain time periods.

The lack of market transparency, illiquidity and high object costs limited participation to a select class of wealthy individuals. Thus, most research concerns developed markets, representing wealthy societies and countries. However, newly created wealth in emerging markets, especially in China, Russia and the Middle East, has increased the number of participants in the art trade. Accordingly, art price indexes for emerging markets have been also evaluated ${ }^{4}$.

The Polish domestic art market is relatively small but the last ten years have seen it develop significantly. This paper attempts to estimate returns from investment in Polish paintings. The aim of the research ${ }^{5}$ is to estimate hedonic art price indexes using direct and indirect approaches. The data used for this study is a selected sample of paintings sold at auctions held by auction houses and foundations in Poland between 2007 and 2013.

\section{Development of the art market}

The global art market was worth $€ 47.4$ billion (total sales of art and antiques) in 2013. This was close to the 2007 value, which was the highest ever recorded (see Table 1) and represents a recovery from the 2009 low resulting from the effects of the world financial crises on the art market. This means that the global art and antiques market has almost returned to the extraordinary heights of the pre-recession boom years powered by US buyers and by rising prices for major post-war and contemporary artists. In 2013, the US accounted for $38 \%$ of the global market by value, China $24 \%$, the UK $20 \%$, France $6 \%$, Switzerland 2\%, Italy, Germany, Austria and Sweden 1\% each, and the rest of the world for $6 \%$. Breaking down European figures, the UK accounted for $63 \%$ of the market value, France 19\%, Germany 5\%, Italy 3\%, Austria 2\%, Sweden 2\%, Spain 1\%, the Netherlands $1 \%$ and the rest of the European Union 4\%. The European Union as a whole comprised 32\% of the world market in 2013 (McAndrew, 2014).

The 2014 TEFAF confirms the flagging market for Impressionist and Modern art in recent years. In 2013, Post-War and Contemporary sales continued to dominate the market,

\footnotetext{
${ }^{3}$ Campbell (2008), Chanel et al. (1996), Ginsburgh et al. (2005), Ashenfelter and Graddy (2003) are good examples.

${ }^{4}$ For instance Kraeussl and Logher (2008) consider art markets in China, Russia and India, while Lucińska (20I2), Kompa and Witkowska (2013) and Witkowska (20/4) analyze price indexes of Polish paintings.

${ }^{5}$ Investing in Paintings on the Financial Market, research conducted under the National Science Centre Grant No. 2012/05/ B/HS4/04/88.
} 
representing $46 \%$ of sales by value and $44 \%$ by volume. The sector's market value grew $11 \%$ in 2013 with respect to the previous year. Among the lots offered in 2013, the number of high-value works (i.e. artworks sold for over US $\$ 1$ million) increased almost $10 \%$ compared to 2012, with 113 works selling for over US\$10 million, a new record in auction history. Collectively, these works accounted for over US $\$ 2.6$ billion, and represented $18 \%$ of global Fine Art sold that year by value. The top 10 artists in 2013 by value sold at auction include: Andy Warhol, whose works were sold for US\$427.1 million, Pablo Picasso - US\$422.8 million, Zhang Daqian (Chang Dai-Chien) - US\$320.6 million, Jean-Michel Basquiat - US\$286.8 million, Qi Baishi - US\$265.6 million, Francis Bacon - US\$219.8 million, Gerhard Richter - US\$189 million, Roy Lichtenstein - US\$160.9 million, Zao Wou-Ki - US\$158.3 million, and Claude Monet - US\$157.1 million (Markley, 2014).

The growth of the art market reflects the observed increase in the number of global High Net Worth Individual ( $\mathrm{HNWI}$ ) over the last ten years, and it is likely that the art market will continue to grow in line with the global population growth of HNWI. The price of art is expected to rise because of the shortage of suitable art and the future increase in buying power, resulting from the economic recovery. The growth of the art market and its infrastructure in recent years is fueling an increasing interest in art as an asset class. Accordingly, we start to see the early stages of an art finance industry ${ }^{6}$.

\section{Table 1. Comparison of global and Polish art markets}

\begin{tabular}{|c|c|c|c|c|c|c|}
\hline \multirow[b]{2}{*}{ Years } & \multicolumn{3}{|c|}{ International market } & \multicolumn{3}{|c|}{ Polish market } \\
\hline & $\begin{array}{c}\text { Total value } \\
\text { (€bn) }\end{array}$ & $\begin{array}{c}\text { Number of } \\
\text { transactions }\end{array}$ & $\begin{array}{c}\text { Average Value } \\
(€)\end{array}$ & $\begin{array}{c}\text { Total value } \\
\text { (€bn) }\end{array}$ & $\begin{array}{c}\text { Number of } \\
\text { transactions }\end{array}$ & $\begin{array}{c}\text { Average Value } \\
(€)\end{array}$ \\
\hline 2002 & 22.3 & n.a. & & n.a. & 2439 & n.a. \\
\hline 2003 & 18.6 & 25400000 & 732.3 & n.a. & 2595 & n.a. \\
\hline 2004 & 24.4 & 26600000 & 916.7 & n.a. & 2808 & n.a. \\
\hline 2005 & 28.8 & 28200000 & 1022.4 & n.a. & 2999 & n.a. \\
\hline 2006 & 43.3 & 32100000 & 1349.9 & n.a. & 2975 & n.a. \\
\hline 2007 & 48.1 & 49800000 & 965.2 & n.a. & 3212 & n.a. \\
\hline 2008 & 42.2 & 43700000 & 964.7 & n.a. & 3540 & n.a. \\
\hline 2009 & 28.3 & 31000000 & 914.0 & n.a. & 3427 & n.a. \\
\hline 2010 & 43.0 & 35100000 & 1223.7 & n.a. & 3886 & n.a. \\
\hline 2011 & 46.4 & 36800000 & 1260.9 & 0.01180 & 5384 & 2192.6 \\
\hline 2012 & 44.1 & 35500000 & 1242.3 & 0.01476 & 6591 & 2238.8 \\
\hline 2013 & 47.4 & 36500000 & 1298.6 & n.a. & n.a. & n.a. \\
\hline Dynamics 2012/2003 & 237.10 & 139.76 & 169.64 & & 253.99 & \\
\hline Dynamics 2012/2011 & 95.04 & 96.47 & 98.52 & 125.00 & 122.42 & 102.11 \\
\hline
\end{tabular}

SOURCE: OWN ELABORATION ON THE BASIS OF DATA FROM MCANDREW (2014) ${ }^{7}$ AND GAJEWSKI AND POTOCKI (20I3), P. 11.

${ }^{6}$ There were an estimated 7.2 million High Net Worth Individuals in 2000 and by 2010 this number had increased by $51 \%$ to 10.9 million http://www.artassure.com/art-market-analysis-2013/.

${ }^{7}$ Quoted from International art market 2013: new report examines the facts and figures, http://www.theguardian.com/cultureprofessionals-network/culture-professionals-blog/20/4/mar//9/international-art-market-2013-facts-figures (7/08/20/4) 3 
The Polish domestic art market has been developing dynamically (see Table 1), although it is still small; in 2012 it generated only $0.03 \%$ of world transaction value and $0.02 \%$ of transaction lots, which was the highest result recorded after 1989 (Deloitte, 2013). It can be seen that the number of transactions in Poland was 2.5 times greater in 2012 compared to 2003 (while the number in the international market was 1.4 times greater), and the average transaction value is 1.8 times greater than in the world market. According to the report ${ }^{8}$ there were only 10 auction houses and 578 art galleries and antique shops selling artworks. Bearing in mind the relatively high average prices per transaction (Table 1) in Poland, it may suggest that only valuable pieces of art appear at auctions and might be proof of the fact that - as in the global market - private transactions in Poland are not reported by official sources.

The beginnings of the Polish art market date back to the 19th century, but the art market in Poland was practically inexistent under the communist system. This was due to two main factors: the typically low incomes in society as a whole; and the fact that at that time all artworks and crafts which had been produced before 1945 were treated as national heritage. However, even then several art galleries and artist associations were buying and selling art, mostly that produced by domestic artists or from other Soviet bloc countries. Over the 25 years of economic transformation in Poland, essential changes in the income distribution and the structure of consumption took place. Thus, there has been increasing interest in artworks, which can be considered either as an aesthetic attraction or as an investment opportunity. There has been a notable development of the art market in Poland which can be measured by the increasing number of art auctions, from 8 in 1989 to 122 in 2012, as well as the relatively high accumulated auction turnover - US\$180 million between 1991 and 2011 (Gajewski and Potocki, 2013) - and the fact that the first Art Fund was established in 2011.

The structure of the Polish art market is presented in Table 2. Paintings are the most popular medium, both in terms of number of lots (56\%) and transaction value (72\%). In Poland there are no individual sales organized for Old Masters and Modern Art, and the year 1945 is used as the main delimitation for art market segments. Another characteristic of the auction market in Poland is the increasing role played by the young generation of artists. Whereas in the twentieth century "pre-1945 art" accounted for almost $90 \%$ of the market in terms of number of lots, in the first half of 2012 this share was only $26 \%$, although it represented $61 \%$ in terms of value. The share of the "UltraContemporary art" (i.e. the work of artists under 40 years old) in the market increased from $0.5 \%$ in 2005 to $44 \%$ of artworks sold in 2012 , with $8 \%$ capitalization. This trend is consistent with the tendency observed in the global art market; in terms of transaction

$\overline{8}$ Białynicka-Birula (2009), pp. 45-95. 
values the percentages of Post-War and Contemporary art in the global and the Polish market (including Ultra-Contemporary art) are similar. Likewise, the Mei Moses World Post-War Contemporary Index has greatly outperformed the Mei Moses World Impressionist Modern Index, particularly over the last 10 years.

Table 2. Structure of the Polish art market in the first half of 2012 by mediums and segments

\begin{tabular}{lrrlrr}
\hline Mediums & Lots [\%] & Value [\%] & Mediums & Lots [\%] & Value [\%] \\
\hline Sculpture & 2 & 1 & Graphic & 14 & 2 \\
\hline Photography & 1 & 0 & Drawing & 17 & 20 \\
\hline Arts \& Crafts & 10 & 5 & Painting & 56 & 72 \\
\hline Segments & Lots [\%] & Value [\%] & Segments & Lots [\%] & Value [\%] \\
\hline Post-War and Contemporary & 30 & 31 & Ultra-Contemporary & 44 & 8 \\
\hline Pre-1945 art & 26 & 61 & & &
\end{tabular}

SOURCE: OWN ELABORATION ON THE BASIS OF DATA FROM GAJEWSKI AND POTOCKI (20I3).

Polish art has also been represented at global auctions, with a total trading value of US\$31.9 million in 2009, US\$2.4 million in 2010, US\$23 million in 2011 and US\$12.3 million in 2012. There are five Polish artists whose works sold for more than US\$1 million: Tamara de Lempicka, Henryk Siemiradzki, Roman Opałka, Max Weber and Piotr Uklanski. Together they achieved a total capitalization of US\$99.3 million (for 35 lots), while Tamara de Lempicka alone generated US\$87.2 million26 artworks (Gajewski and Potocki, 2013). It is also worth mentioning that there are two Polish artists among the Top 500 Contemporary Artists 2012/2013: Piotr Uklanski (born in 1969) in 314th position, and Sasnal Wilhelm (born in 1972) in 401st position.

\section{Hedonic art price index construction and returns from art investment}

In order to determine whether art is a profitable investment, it is necessary to estimate expected returns from such investment. Historical returns can be measured by applying art price indexes. However, there are several limitations to using such measures of art performance because, typically, only auction records are used. Though there is extensive auction data representing a wide range of price points and collecting categories, much of the turnover in the market (i.e. private sales) is not captured. In addition, transaction costs and other fees are not fully reflected. Auction fees for the buyer can exceed 10 to $20 \%$ of the hammer price. Other ongoing expenses such as storage, insurance, advisory and appraisal costs may also consume part of the returns (Sommer, 2013). 
The major motivations behind construction of art price indexes are (Ashenfelter and Graddy, 2006; Ginsburgh et al., 2006): (1) to measure the financial performance of art, relative to other alternative forms of investment, (2) to check whether adding art to a diversified market portfolio can lower the overall risk and/or increase the rate of return, and (3) to outline general trends on the art market. Construction of an art price index dedicated to a particular market requires several decisions as to the choice of the index methodology and selection of the sample which is used to evaluate the market performance.

Having price indexes describing price relation in two neighboring periods $t(t=1,2, \ldots, T)$, i.e. , allows calculation of the price index $T I_{t}$ concerning price changes in comparison to the first $(t=0)$ period of analysis, i.e.: $T I_{t}=I_{1} \cdot I_{2} \cdot \ldots \cdot I_{t}$. Therefore the total index $T I_{T}$ gives information about price movements during the whole period under study since it compares prices in the last period $t=T$ to those in the first period $t=0$. Then, returns from investment in art obtained period by period equal $C_{t}=\left(I_{t}-1\right) \cdot 100 \%$, while total return in the whole analyzed period is $T C_{T}=\left(T I_{T}-1\right) \cdot 100 \%$. It is also possible to calculate the average return for a particular period by taking the total returns from the entire period under study and employing the geometric mean, $G M$ :

$$
G M=\sqrt[T]{\prod_{t=1}^{T} I_{T}}=\sqrt[T]{T I_{T}}
$$

In such a case, the average return equals: $G=(G M-1) \cdot 100 \%$.

There are several methodologies for producing art price indexes, such as naive price index, repeat-sales, average price (geometric mean), composite price (basket) index, and hedonic index (Renneboog and Spaenjers, 2009). For example, Anderson (1974), Pesando (1993), Pesando and Shum (1999), and Mei and Moses (2002) employed repeat sales, Mok et al. (1993) and Landes (2000) used geometric repeat sales, Ginsburgh and Schwed (1992), Kraussl and van Elsland (2008), Higgs and Warthington (2005), and Renneboog and van Houtte (2002) employed the hedonic index method, Candela et al. (2004) used the quality adjusted price approach, and Renneboog and van Houtte (2002) employed a basket index. Burton and Jacobsen (1999) used a composite index based on selected sample sets that vary over time, hedonic regression and repeat sales. Chanel et al. (1996), who apply both the repeat sales and hedonic regression method, conclude that the use of a hedonic index leads to more precise estimates of returns that allow for the inclusion of all observed transactions instead of solely artwork sold at least twice. However, one of the drawbacks of the hedonic method is that it depends on the characteristics used to describe the artworks, and on the functional form of the regression model (Ginsburgh et al., 2006). Research provided by Chanel et al. (1996) indicates that over long periods the results produced with the respective methodologies are closely correlated. Issues regarding the various index pricing 
methodologies are highlighted in Ginsburgh et al. (2006), which specifically compares hedonic to repeat sales regression. Ashenfelter and Graddy (2003) and Renneboog and Spaenjers (2009) provide a survey of average returns estimated from art price data.

Naive art price indexes are constructed using average and median auction prices. In this method, a basket of representative paintings is created and tracked over time. This approach avoids the repeat-sales restrictions but instead requires aggregation based on some a priori criteria in order to construct a so-called "average painting" (Candela and Scorcu, 1997).

The repeat-sales methodology considers only those artworks that were sold at least twice with their prices recorded in the period under study. This methodology, therefore, requires a transparent and liquid market. Ginsburgh et al. (2006) argue that repeat-sales regression should not be applied to periods shorter than 20 years, since the number of observations may be too small to obtain reliable results. This methodology is used in the Mei Moses Fine Art Index.

The main advantage of the hedonic index approach is that it allows for the inclusion of all traded objects. An art price index can be constructed by employing hedonic regression, which is a method for estimating an approximate value of a piece of art adjusting the average price of the artist's works according to the qualitative characteristics which are incorporated into the hedonic model. Hedonic price functions describe the relationship between the price of a product and its attributes. The analytic function is determined by distributions of buyers and sellers and their preferences as well as the structure of competition in the market (Neiheim, 2006).

The art market index should outline general market trends in the same way as other indexes that are constructed to describe different markets or their segments or sectors, for example the S\&P 500 for the US stock market. This implies that an objectively defined criterion should be used, which poses minimal constraints on the selection of data. Ginsburgh et al. (2006) argue that representativeness, liquidity and capacity are the most important attributes of an index. The most widely-used criterion in the academic literature has been the "position" and relevance of the artist according to the professional literature. However, Kraeussl and van Elsland (2008) argue that from the investors' point of view -the availability of artworks is a better criterion, as the index then represents objects that are actually traded on the market. Selection of artists based on the number of trades, therefore, instead of the expert-determined relevance, increases the influence of artworks that are more available and relatively liquid. In practice, those artists with the highest number and volume of transactions made during art auctions are used (for instance, the Citadel Art Price Index takes the top 20,50 and 100 artists in terms of number of sales). 
The question of sample selection in terms of sample size, and the criteria for object selection, is crucial in determining the fixed basket of representative artworks and this selection should be carried out by experts. However, this issue also arises when applying other methods; different research papers employ a range of different criteria in artwork selection. The most commonly-used criteria in the literature are:

Mediums: for instance, Locatelli-Biey and Zanola (2002) consider sculptures, Pesando (1993) considers prints, Candela et al. (2004) consider paintings, and Ginsburgh and Schwed (1992) drawings;

Belonging to a certain collection, a criterion favored by Landes (2000), who takes the Ganz collection;

Style or period: Pesando (1993) takes modern prints; Candela et al. (2004) Modern and Contemporary, 19th century, and Old Master paintings; Ginsburgh and Schwed (1992) use Flemish-Dutch, French and Italian Old Master drawings; and the Mei Moses Art Index family includes pre-1950 American, 19th century and Old Master, Impressionist and Modern, Post War and Contemporary, Latin American, British after 1850, and Traditional Chinese works of art;

Authors: good examples are works by Pesando (1993) and Pesando and Shum (1999), who analyze Picasso prints;

- "Spatial" classification: Mok et al. (1993) consider Modern Chinese paintings; Kraussl and van Elsland (2008) German paintings in general; and Higgs and Warthington (2005) Australian paintings, among others;

Repeat-sales: for example, the Mei Moses database, which only includes artworks that have been sold more than once;

Auctioneer or place of sale, usually limited to the most famous auction houses, namely Sotheby's and Christie's (and their predecessor firms): the Mei Moses All Art Index, the most widely-used benchmark in the analysis of financial returns of the art market, is mainly based on paintings sold in New York and London. The Mei Moses World All Art Index and seven indexes, representing different collecting categories, are estimated using data (excluding online sales) collected from two companies, Sotheby's and Christie's. However, regional markets are also sometimes considered, for instance Higgs (2012) studies the Australian market, and Lucińska (2012), Kompa and Witkowska (2013), and Witkowska (2014) focus on Polish art markets.

It should be noted that such an arbitrary choice is open to criticism on the grounds that the selected artworks may not be representative of the whole market. All published indexes rely on data from just half of the art market, i.e. the auction market, while $53 \%$ of the global art market is actually made up of private gallery and dealer sales, according to the latest TEFAF report. However, employing data based on public 
auction results ensures the transparency of art indexes. Typically, art indexes track the most successful art sales at auction; in some cases, artworks that have successfully sold at auction more than once, while omitting artworks that fail to sell at auction (around a quarter of all lots). Data used for the index construction usually excludes "bought-in" art pieces that were not sold due to the fact that the bid was below an unknown reservation price ${ }^{9}$. The size of the sample depends on the period under study, that is, the time span when artworks are sold.

In our research, the hedonic regression methodology is used to construct an art price index because of the limited scale of the art market in Poland. Artworks are heterogeneous assets, with a variety of physical and non-physical characteristics that make them unique, including artist reputation, materials used, the period of production and subjective traits such as quality. The price of an artwork, therefore, depends on all these characteristics. In our study, we employ direct and indirect approaches to the hedonic index estimation, both of which are based on the hedonic regression function (pooled regression) that usually takes the following form (Renneboog and Spaenjers, 2013):

$$
\ln P_{i, t}=\alpha_{0}+\sum_{j=1}^{k} \alpha_{j} X_{i j, t}+\sum_{j=1}^{\tau} \beta_{t} Z_{i, t}+\varepsilon_{i, t}
$$

where $\alpha_{j}$ and $\beta_{t}$ are the coefficient values of the characteristic $X_{j}$ and time dummy variable $Z_{t}$, which takes the value 1 if the painting $i$ is sold in the period $t$ and takes the value 0 otherwise, and $\varepsilon_{i t}$ is the disturbance term.

One of the underlying assumptions is that the price of an artwork essentially depends on its quality, which is to a great extent quantifiable. The explanatory variables $X_{j}$ represent characteristics of the objects, such as the artist, size, format, technique, materials, period, subject of the artwork, signature and artist's living status, or are related to the sale, including auctioneer, location and date of sale. These attributes are usually qualitative so they are represented by binary variables in the relation (2). The dependent variable in hedonic models is usually the natural logarithm of the sale price. All auctions relating to an artist are included in the calculation in order to avoid selection bias. The time dummy variables can be annual, semi-annual, quarterly or even monthly depending on the frequency of trading. The hedonic approach essentially entails running an Ordinary Least Squares (OLS) regression.

The hedonic regression method therefore controls for quality changes by attributing implicit prices to a set of value-adding characteristics. In other words, hedonic

\footnotetext{
${ }^{9}$ See Tully (20/4) and http://www.artasanasset.com/main/computation.php. $\square$
} 
regressions strip the observable characteristics from the artworks to obtain an index reflecting the price of a "standard artwork" (Renneboog and van Houtte, 2002).

Hedonic models require knowledge of the artworks' characteristics and the mechanisms driving art prices. The main weakness of this methodology lies in the limitation of attributes used as explanatory variables and the arbitrariness of their selection. Therefore, application of the hedonic index methodology requires decisions about (a) the form of the price index, for instance, a direct or indirect approach, (b) selection of explanatory variables in the hedonic regression, (c) selection of artworks and variables used for art price modeling.

In order to estimate the price index, parameter estimates $\hat{\alpha}_{j}, \hat{\beta}_{t}$ are employed. The simplest way to produce the art price index is to treat time variables as a sub-group of characteristics that influence the price of a painting. In other words the hedonic total index HTI in the period tequals (Ginsburgh, 2005; Renneboog and Spaenjers, 2013):

$$
H T I_{t}=e^{\hat{\beta}_{t}} .
$$

A similar approach is presented by Ginsburgh et al. (2006), where the hedonic function is:

$$
\ln P_{i, t}=\sum_{j=1}^{k} \alpha_{j} X_{i j, t}+\sum_{t=0}^{\tau} \beta_{t} Z_{i, t}+\varepsilon_{i, t}
$$

i.e. the constant term is missing and all time dummies are present in the model. Using parameter estimates $\hat{\beta}_{t}$ from the model (4), the hedonic indexes $H T$ are calculated as:

$$
H I_{t}=\frac{e^{\hat{\beta}_{t}}}{e^{\hat{\beta}_{t-1}}} .
$$

for $t=1,2, \ldots, T$, and $H I_{0}=1$.

Such an approach is used to calculate the Citadel Art Price Index, as well as in the research by Edwards (2004) and Higgs (2010), among others. Applying the parameter estimates $\hat{\beta}_{t}$ corresponding to time dummies is called the direct approach since the hedonic index is calculated directly from the regression model (2) or (4).

A different (indirect) approach to the hedonic index estimation is to apply the hedonic quality adjustment $H Q A$ calculated on the basis of the parameter estimates $\hat{\alpha}_{j}$ from the model (2). Then, the formula for the hedonic index $(H I)$ is as follows (Kraeussl and van Elsland, 2008):

$$
H I_{t}=\frac{N I_{t}}{H Q A_{t}}=\frac{\prod_{i=1}^{n}\left(P_{i, t}\right)^{1 / n} / \prod_{i=1}^{m}\left(P_{i, t-1}\right)^{1 / m}}{H Q A_{t}},
$$


where at time $t: N I_{t}$ is the naive price index, $P_{i, t}$ is the price of the $i^{\text {th }}$ artwork, and $H Q A_{t}$ represents the hedonic quality adjustment.

The hedonic quality adjustment describes changes in quality, style, mode and type of the artworks, and is defined as follows:

$$
H Q A_{t}=\exp \left[\sum_{j=1}^{k} \alpha_{j}\left(\sum_{i=1}^{n} \frac{X_{i j, t}}{n}-\sum_{i=1}^{m} \frac{X_{i j, t}}{m}\right)\right],
$$

where $X_{i j, t}$ is the observation of the $j^{t h}$ feature characterizing the $i^{\text {th }}$ artwork at time $t$, $m$ and $n$ are numbers of lots sold in the periods $t$ and $t-1$ respectively, and $\hat{\alpha}_{j}$ are the parameter estimates of the hedonic regression (2).

The naive price index $(N I)$ describes an "average painting" from the aggregation of all artworks that make up the sample selected as representative of the art market or a particular segment. The hedonic index allows the tracking of short-term price movements and returns in this market. It offers a better understanding of how the market performed over the period under study. The performance of this market can then be compared to investments in traditional financial assets.

\section{Art investment}

There are intangible values associated with owning and enjoying artworks. Firstly, art provides collectors with social status and prestige, in other words art is a means of signaling their wealth or lifestyle to others. Secondly, there are the philanthropic benefits of purchasing art, from financing up-and-coming artists to building a collection that serves to preserve cultural heritage. Thirdly, monetary benefit is the opportunity to gain a return on investment, though investors also recognize art as a way to store value, to hedge inflation and to diversify their portfolio allocation.

The recent global financial crisis has demonstrated the need for diversification in a traditional investment portfolio of stocks, bonds and property. A diversified portfolio reduces overall risk and with an allocation of tangible assets such as art, is likely to be less volatile. Art tends not to fluctuate as much as the stock market and art investment portfolios can provide strong income streams in addition to potential long-term capital growth.

Artworks as investment assets are characterized by certain features:

- The current market value is difficult to evaluate since there is no "natural value", which could be used as reference or fair value. The price of an artwork is limited 
only by the amount of money that collectors are willing and able to pay for it (Goetzmann et al., 2011).

Art investments are undivided and illiquid in comparison to "classical" financial assets.

Artworks are often expensive and additional purchase/sale costs may be high (from 10 to $25 \%$ of hammer price for artworks while equivalent costs in financial markets are about $1 \%$ of sale price).

Artworks seem to be long-lasting investments.

There are also several risks (besides the risk of price variability of investment instruments) that are unique to the art market (Frey and Cueni, 2013):

Buyers can never be certain that the purchased object is an original and not a copy or forgery. Even if the artwork is an original piece, it is difficult to know who the painter was: the master himself, the circle, the school, or perhaps the painting was only in the style of a grand master. For instance, Frey and Pommerehne (1989b) describe the story of the painting "Daniel in the Lion's Den".

Paintings which have been repainted, damaged, improperly renovated or stored, may suffer a drop in value.

Owners of art pieces may fear that the masterpieces they possess could be stolen, destroyed (by fire, revolution, etc.) or seized by their government as a part of "national heritage".

Possession of valuable art can necessitate additional payment of taxes (sale or property taxes) and the government may impose new export restrictions.

Tastes and fashions change over time and the art market is characterized by extreme heterogeneity, thus it is impossible to predict whether a certain artist will "fall out of fashion" at some point in the future. Renneboog and Spaenjers (2013) report 220 artists who were included in the 1926, 1959 and 1980 editions of Gardner's Art through the Ages ${ }^{10}$, but who subsequently "fell out of fashion" and were not included in either the 1996 or the 2004 edition.

Art belongs to the group of luxury goods and its price is very sensitive to the general economic situation and income changes. Goetzmann et al. (2011) present the evidence that personal income of the highest earners determines the price of art; a $1 \%$ fall in income of the earners in the top $0.1 \%$ income distribution in the UK triggers a decline in art prices of nearly $10 \%$.

- Behavioral anomalies seem to play an important role in the art market since collectors are usually unwilling to sell pieces of art from their collections and they tend to buy art created by domestic artists.

${ }^{10}$ Gardner's Art Through the Ages is an American textbook on art history that was written by Helen Gardner (1878-1946) and published for the first time in 1926. Co-authors of the 2004 edition are F.S. Kleiner and Ch.J. Mamiya. 
Renneboog and Spaenjers (2013), on the basis on more than a million auction transactions between 1900 and 2007, representing 10,100 artists, show that art generates returns of only $4 \%$ per year while stocks yield a return over $6.5 \%$. On the other hand, art investment is more profitable than government bonds and gold, which yield returns of $2-3 \%$, and comparable to corporate bonds that also gave an average annual return of $4 \%$. However, risk measured by standard deviation is higher for gold (more than 24\%) than for art (10\%), equities (16.5\%), government bonds (less than $11 \%)$ and corporate bonds (9.5\%). Nevertheless, the results suggest that investment in art seems to be a comparatively safe asset class that can serve as a hedging instrument against inflation and allow diversification of the investment portfolio since art is not correlated with equities or bonds but rather associated with tangible assets such as gold or commodities.

Returns from investments in art may be very attractive for investors especially in light of the turbulence of the financial market. Table 3 shows the annual returns from art and standard financial assets evaluated for the years 1955-2005.

Table 3. Comparison of annual rates of return evaluated for the time span 1955-2005

\begin{tabular}{lcccc}
\hline Period & Mei Moses all art index & S \& P 500 & US 10-year bonds & Gold \\
\hline 50 years & $10.47 \%$ & $10.95 \%$ & $6.64 \%$ & $5.17 \%$ \\
\hline Last 25 years & $7.97 \%$ & $13.51 \%$ & $9.81 \%$ & $-1.11 \%$ \\
\hline Last 5 years & $7.27 \%$ & $-2.40 \%$ & $7.47 \%$ & $8.97 \%$ \\
\hline
\end{tabular}

SOURCE: WWW.ARTTRUST.COM QUOTED AFTER POTOCKI (20I2).

According to the Deloitte (2013) report, the average annual return from 800 repeat sales that took place in Poland during the last 20 years, was $25.7 \%$ while over the same time period, equity returns measured by the Warsaw Stock Exchange Index WIG20 were only 8.7\% (Gajewski and Potocki, 2013). The annual return from artworks held for more than 15 years was $46.6 \%$ while investments horizons shorter than 5 years yielded only $0.2 \%$. Thus the time span of investments is crucial to the returns generated.

\section{Empirical results}

In an empirical study the main problem is deciding on the period of analysis and on the objects to be included in the art price index. As mentioned previously, researchers have used a variety of different criteria to select the artists whose artworks are to be included in the index. 
In this research, we only include artworks painted by the Polish artists selected according to the greatest number of lots sold in the period under study. We also incorporate some "younger" artists in order to reflect general tendencies in the Polish art market. Additional criteria for painter selection are: more than 35 lots sold at auctions, and an average price for a single artwork of over 1000 PLN (about $€ 250$ ). Therefore, we select the 17 "most liquid" painters (Table 4). Hedonic models are estimated employing data" from auctions of paintings that took place in Poland in the years 2007-2013.

\section{Table 4. List of Polish painters whose artworks made up the sample}

\begin{tabular}{|c|c|c|c|c|c|c|}
\hline \multirow{2}{*}{$\begin{array}{l}\text { Artist: } \\
\text { name and } \\
\text { symbol }\end{array}$} & & \multirow{2}{*}{$\begin{array}{c}\text { Year of } \\
\text { birth and } \\
\text { death }\end{array}$} & Count & $\begin{array}{l}\text { Value } \\
\text { (PLN) }\end{array}$ & $\begin{array}{c}\text { Average } \\
\text { value (PLN) }\end{array}$ & $\begin{array}{l}\text { Variability } \\
\text { coefficient }\end{array}$ \\
\hline & & & \multicolumn{4}{|c|}{ of artworks sold (2007-2010) } \\
\hline Kossak Jerzy & KOJ & 1886-1955 & 156 & 1992600 & 12773.08 & 0.84 \\
\hline Kossak Wojciech & KOW & $1856-1942$ & 92 & 3134900 & 34075.00 & 1.02 \\
\hline Chmieliński (Stachowicz) Wtadystaw & $\mathrm{CHM}$ & 1911-1979 & 78 & 757800 & 9715.38 & 0.67 \\
\hline Dwurnik Edward & DWU & 1943 & 123 & 726350 & 5905.28 & 0.96 \\
\hline Erb Erno & ERB & $1890-1943$ & 65 & 869300 & 13373.85 & 0.49 \\
\hline Hofman Wlastimil & $\mathrm{HOF}$ & $1881-1970$ & 150 & 3180850 & 21205.67 & 0.86 \\
\hline Malczewski Jacek & MAL & $1854-1929$ & 112 & 13743050 & 122705.80 & 2.23 \\
\hline Nikifor Krynicki & NIK & 1895-1968 & 196 & 484150 & 2470.15 & 0.48 \\
\hline Nowosielski Jerzy & NOW & 1923-2011 & 221 & 10322500 & 46708.14 & 1.36 \\
\hline Dominik Tadeusz & DOM & 1928 & 73 & 1365500 & 18705.48 & 0.86 \\
\hline Wyczótkowski Leon & WYC & $1852-1936$ & 98 & 4761400 & 48585.71 & 1.90 \\
\hline Wygrzywalski Feliks Michat & WYG & $1875-1944$ & 62 & 1045700 & 16866.13 & 0.61 \\
\hline Berdyszak Jan & BER & 1934 & 65 & 300250 & 4619.23 & 1.56 \\
\hline Maśluszczak Franciszek & MAS & 1948 & 43 & 240950 & 5603.49 & 1.21 \\
\hline Borkowska Agnieszka & BOR & 1978 & 37 & 53040 & 1433.51 & 0.53 \\
\hline Ćwiertniewicz Wojciech & CWI & 1955 & 66 & 70250 & 1064.39 & 0.56 \\
\hline Jarmoliński Bartłomiej & JAR & 1975 & 73 & 95690 & 1310.82 & 0.56 \\
\hline Total & & 1710 & 44280 & 2523 & 0.57 & 3.29 \\
\hline
\end{tabular}

SOURCE: OWN ELABORATION BASED ON ANTCZAK (2014).

The artists generating the greatest number of lots sold in the analyzed period were Nowosielski (221), Nikifor Krynicki (196) and Jerzy Kossak (156), while the highest value transactions were for artworks by Malczewski (more than 13 million PLN) and Nowosielski (over 10 million PLN). In our sample, the lowest average values for a single artwork were for paintings by Ćwiertniewicz, Jarmoliński and Borkowska (from 1064 to 1434 PLN), while the highest average values were for Malczewski $(122,706$ PLN), Wyczółkowski (48,586 PLN) and Nowosielski (46,706 PLN). Most of these artists are well known and occupy a certain position in Polish culture. Seven of them are still alive and at least four can be qualified as part of the "younger generation".

\footnotetext{
${ }^{11}$ Data are collected from auctions of paintings held in Poland in 2007-20/3 (see Lucińska, 20I 2, and Antczak, 20I4).
} 
Table 5. Parameter estimates

\begin{tabular}{|c|c|c|c|c|c|c|c|c|c|}
\hline Variables & Variants & Estimates & M1 & Estimates & M2 & Estimates & M3 & Estimates & M4 \\
\hline const & & 7.8674 & $* * *$ & 2.3924 & $\star \star \star ~$ & 2.7697 & $* * *$ & & \\
\hline \multirow[t]{6}{*}{ year } & Y2008 & 0.1391 & $\star * *$ & 0.1441 & $\star * \star$ & 0.1423 & $* * *$ & 0.1441 & $* * *$ \\
\hline & Y2009 & -0.0011 & & -0.0109 & & -0.0055 & & -0.0109 & \\
\hline & Y2010 & -0.0561 & & -0.0566 & & -0.0565 & & -0.0566 & \\
\hline & Y2011 & -0.1671 & $\star \star \star *$ & -0.1523 & $\star \star \star$ & -0.1552 & $* * *$ & -0.1523 & $* \star \star$ \\
\hline & Y2012 & -0.1367 & $\star *$ & -0.1464 & $\star * \star$ & -0.1450 & $\star *$ & -0.1464 & $* * *$ \\
\hline & Y2013 & -0.1696 & $* * *$ & -0.1754 & $\star \star \star *$ & -0.1718 & $* \star *$ & -0.1754 & *** \\
\hline auction & AGRAART & 0.2062 & $* * *$ & 0.1879 & $* * *$ & 0.2159 & $* * *$ & 0.1879 & *** \\
\hline \multirow[t]{7}{*}{ house } & DESA & 0.1832 & $\star *$ & 0.1686 & $\star *$ & 0.1903 & $* * *$ & 0.1686 & ** \\
\hline & DESA_UNI & 0.1759 & $\star * \star$ & 0.1784 & $\star \star \star$ & 0.1984 & $* * *$ & 0.1784 & $\star * \star$ \\
\hline & OKNA_SZTUKI & 0.1137 & & 0.0755 & & & & 0.0755 & \\
\hline & OSTOYA & -0.0111 & & -0.0269 & & & & -0.0269 & \\
\hline & POLSW & 0.6140 & $* * *$ & 0.5951 & $\star * \star$ & 0.6364 & $* * *$ & 0.5951 & $* * *$ \\
\hline & REMPEX & -0.0077 & & -0.0217 & & & & -0.0217 & \\
\hline & RYNEK_SZTUKI & -0.0719 & & -0.1911 & $\star *$ & & & -0.1911 & ** \\
\hline \multirow[t]{16}{*}{ artist } & KOSSAK_J & -1.6323 & $\star * *$ & -1.6464 & 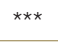 & -1.6368 & $* * *$ & -1.6464 & *** \\
\hline & KOSSAK_W & -0.9178 & $* * *$ & -0.9090 & $\star * *$ & -0.8954 & $* * *$ & -0.9090 & $* * *$ \\
\hline & CHMIELINSKI & -1.4126 & $\star \star \star *$ & -1.4061 & $\star \star \star$ & -1.4135 & $* * *$ & -1.4061 & $* \star \star$ \\
\hline & DWURNIK & -2.0829 & $* \star *$ & -2.0642 & $\star * \star$ & -2.0573 & $* * *$ & 0.3282 & \\
\hline & ERB & -1.1873 & $* * *$ & -1.1959 & $\star \star \star ~$ & -1.2053 & $* * *$ & -1.1959 & *** \\
\hline & HOFMAN & -1.0842 & $* * *$ & -1.0931 & $* * *$ & -1.0863 & $* * *$ & -1.0931 & *** \\
\hline & MALCZEWSKI & 0.1559 & * & 0.1703 & * & 0.1741 & $* *$ & 0.1703 & * \\
\hline & NIKIFOR & -1.2974 & $\star * \star *$ & -1.1847 & $\star * *$ & -1.1934 & $* * *$ & -1.1847 & $* * *$ \\
\hline & NOWOSIELSKI & -0.2810 & $* * *$ & -0.2768 & $\star * \star$ & -0.2673 & $* * *$ & 2.1156 & *** \\
\hline & DOMINIK & -1.5701 & $\star * *$ & -1.5691 & $\star * \star$ & -1.5315 & $* \star *$ & 0.8233 & *** \\
\hline & WYGRZYWALSKI & -1.4410 & $* * *$ & -0.6599 & $\star * \star$ & -1.4786 & $* * *$ & -0.6599 & $* * *$ \\
\hline & BERDYSZAK & -2.3441 & $\star * \star$ & -1.8574 & $\star \star \star$ & -2.3237 & $* * *$ & 0.5350 & $\star \star$ \\
\hline & MASLUSZCZAK & -2.4074 & $* * *$ & -1.5500 & $\star * *$ & -2.3834 & $* * *$ & 0.8425 & $* * *$ \\
\hline & BORKOWSKA & -4.1524 & $\star * *$ & -3.2365 & $\star \star \star ~$ & -4.1502 & $* * *$ & -0.8440 & *** \\
\hline & CWIERTNIEWICZ & -3.4166 & $* * *$ & -2.5625 & $* * *$ & -3.4040 & $* * *$ & -0.1701 & \\
\hline & JARMOLINSKI & -4.3471 & $\star \star \star *$ & -3.4697 & $\star \star \star$ & -4.2982 & $* * *$ & -1.0773 & $* \star \star$ \\
\hline signature & SYGN & 0.0386 & & 0.0659 & & & & 0.0659 & \\
\hline \multirow[t]{8}{*}{ technique } & watercolor & 0.9552 & $* * *$ & 1.0034 & $\star \star \star ~$ & 0.9284 & $* * *$ & 1.0034 & *** \\
\hline & acrylic & 1.0804 & $* * *$ & 1.2272 & $* * *$ & 1.0769 & $* * *$ & 1.2272 & *** \\
\hline & gouache & 0.9329 & $* * *$ & 1.1100 & $\star * \star$ & 0.9298 & $* \star *$ & 1.1100 & $* * *$ \\
\hline & oil & 1.7818 & $\star * \star *$ & 1.8576 & $\star * *$ & 1.7810 & $* * *$ & 1.8576 & $* * *$ \\
\hline & pencil & 0.6264 & $* * *$ & 0.8203 & $\star * \star$ & 0.6720 & $* * *$ & 0.8203 & *** \\
\hline & pastel & 1.2906 & $* * *$ & 1.3732 & $\star * \star$ & 1.2854 & $* * *$ & 1.3732 & *** \\
\hline & tempera & 0.8376 & $* * *$ & 1.1712 & $\star * \star$ & 1.0115 & $* * *$ & 1.1712 & $* * *$ \\
\hline & drawing ink & 0.3654 & $\star * \star$ & 0.4597 & $\star \star \star$ & 0.3517 & $* * *$ & 0.4597 & $* \star \star$ \\
\hline \multicolumn{2}{|c|}{ Price relation } & 0.2997 & * & -0.0109 & & & & -0.0109 & \\
\hline \multicolumn{2}{|l|}{ Alive } & & & & & & & 2.3924 & *** \\
\hline \multicolumn{2}{|c|}{$\ln ($ surface area) } & -0.3541 & & 0.5305 & $* * *$ & 0.5080 & $* * *$ & 0.5305 & $* * *$ \\
\hline \multicolumn{2}{|c|}{$\ln \left(\right.$ surface $\left.a r e a^{2}\right)$} & 0.0361 & $\star \star \star *$ & & & & & & \\
\hline \multicolumn{2}{|c|}{ Adjusted $R^{2}$} & 0.8337 & & 0.8323 & & 0.8358 & & 0.8363 & \\
\hline
\end{tabular}

SHADOWED CELLS DENOTE THE VARIABLES NOT INCLUDED IN MODELS MI, M2, M3 AND M4. 
In our study, we select several explanatory variables, which are usually applied in hedonic models constructed for art price indexes. They describe the artist's and exhibitor's reputation, type and quality of the artwork as well as conditions of the transaction. Auction house describes the reputation of the auctioneer and this variable is specified as a number of dummies defined as auctioneer names, and the reference variant is other auctioneers. Artist reputation is defined by the name of a painter that is represented by the variable artist, and Wyczótkowski is the reference painter. Whether or not an artist is still alive is also often incorporated to hedonic models since the death of an artist causes production to stop and may cause prices to rise. For this study, the variable Alive equals 0 if the artist is still alive.

Type and quality of the art piece is described by several variables such as: signature, technique and surface of the painting. The type of work is characterized by the technique and materials used, and this variable is specified as a number of dummies that indicate whether the art piece represents a certain type of work. The reference variant here is other techniques. Signature is one of the artwork attributes; it equals 1 if the signature is visible. Surface $\left(\mathrm{cm}^{2}\right)$ of the artwork is the most commonly-used variable to describe the physical characteristics of a painting. In general, the parameter estimates for this variable should be positive, however, larger works may be difficult to display thus in some models squared surface is applied (with negative influence). In the models, we use natural logarithms of surface area.

Conditions of the transaction are represented by two variables: year and price relation. Year of sale is a set of binary variables defined as the year of transaction. The reference level of this variable is the year 2007 (Y2007). Price relation refers to the relation between the reserve and hammer price: the variable equals 1 if the former is greater than the latter, since in such cases a sale might not take place (so-called 'conditional sale').

In this paper, we present four selected models (2) estimated OLS on the basis of the sample described above $(N=1710)$. The parameter estimates are presented in Table 5. Determination coefficients for all models are above $83 \%$, and the variables signature and price relation are statistically insignificant in all models. Alive is introduced only in models without a constant term due to collinearity. In the model M1, all parameter estimates (those corresponding to authors can be easily checked since Malczewski's artworks were the most expensive among the selected painters) are correct except parameters corresponding to surface area. Both parameters should be significantwith the variable for $\ln \left(\right.$ surface $\left.^{2}\right)$ negative and the variable for $\ln ($ surface $)$ - positive however, the latter variable is statistically insignificant. Thus, in other models presented only $\ln ($ surface) is included, and it is significant and positive in all models. Some doubts arise concerning the parameter estimates for authors in the model M4 since they are significant and positive for several authors, which is not correct. 
Therefore only the M2 and M3 models should be used for the art price index construction.

\section{Hedonic art price indexes}

In our research, we estimate naive $N I_{t}$ (as given in (6)) and hedonic $H I_{t}$ price indexes employing direct and indirect approaches for the models M2-M3. The former $\mathrm{HI}_{t}(3)$ is evaluated on the basis of the parameter estimates corresponding to time dummies in models (2), and the latter $H I_{t}(6)$ by employing formulas (6) and (7). Table 6 shows a comparison of the indexes. The row "Total" contains the total index value describing price changes in 2013 with respect to the base year 2007. The row "Average" contains the geometric mean (1) describing the average annual price changes.

Table 6. Comparison of indexes

\begin{tabular}{|c|c|c|c|c|c|c|c|c|c|c|c|c|}
\hline \multirow[t]{2}{*}{ Year } & \multicolumn{2}{|c|}{ Annual index $I_{t}$} & \multicolumn{2}{|c|}{ Return $C_{t}$} & \multicolumn{2}{|c|}{ Annual index $I_{t}$} & \multicolumn{2}{|c|}{ Return $C_{t}$} & $I_{t}$ & \multirow[t]{2}{*}{$C_{t}$} & \multirow{2}{*}{\multicolumn{2}{|c|}{$\frac{I_{t} \quad C_{t}}{\text { WIG }}$}} \\
\hline & $H I_{t}(3)$ & $H I_{t}(6)$ & $H I_{t}(3)$ & $H I_{t}(6)$ & $H I_{t}(3)$ & $H I_{t}(6)$ & $H I_{t}(3)$ & $H I_{t}(6)$ & $N I_{t}$ & & & \\
\hline & \multicolumn{4}{|c|}{ M2 } & \multicolumn{4}{|c|}{ M3 } & & & & \\
\hline 2008 & 1.1550 & 1.4250 & 15.5 & 42.5 & 1.1529 & 1.2032 & 15.29 & 20.32 & 1.4333 & 43.33 & 0.4893 & -51.07 \\
\hline 2009 & 0.8564 & 0.7553 & -14.36 & -24.47 & 0.8626 & 0.8228 & -13.74 & -17.72 & 0.5789 & -42.11 & 1.4685 & 46.85 \\
\hline 2010 & 0.9553 & 0.7949 & -4.47 & -20.51 & 0.9503 & 1.0528 & -4.97 & 5.28 & 0.7444 & -25.56 & 1.1877 & 18.77 \\
\hline 2011 & 0.9087 & 0.9149 & -9.13 & -8.51 & 0.9060 & 0.8645 & -9.4 & -13.55 & 0.8145 & -18.55 & 0.7917 & -20.83 \\
\hline 2012 & 1.0059 & 1.0390 & 0.59 & 3.9 & 1.0103 & 1.0280 & 1.03 & 2.8 & 1.1943 & 19.43 & 1.2624 & 26.24 \\
\hline 2013 & 0.9714 & 1.0579 & -2.86 & 5.79 & 0.9736 & 0.9211 & -2.64 & -7.89 & 1.1154 & 11.54 & 0.9513 & -4.87 \\
\hline
\end{tabular}

Indexes and geometric mean evaluated for the base year 2007 together with total and average annual returns

\begin{tabular}{|c|c|c|c|c|c|c|c|c|c|c|c|c|}
\hline & \multicolumn{2}{|c|}{$T I_{T}$} & $T C_{T}$ & \multicolumn{2}{|r|}{$T I_{T}$} & \multicolumn{2}{|c|}{$T C_{T}$} & \multicolumn{2}{|c|}{$T I_{T}$} & $T C_{T}$ & $T I_{T}$ & $T C_{T}$ \\
\hline Total & 0.8391 & 0.8605 & $-16.09-13.9$ & \multicolumn{2}{|c|}{0.84210 .8532} & -15.79 & -14.68 & \multicolumn{2}{|c|}{0.6703} & -32.97 & 0.8113 & -18.87 \\
\hline Annual & 0.9712 & 0.9753 & $-2.88 \quad-2.47$ & 0.9 & 80.9739 & -2.82 & -2.61 & \multicolumn{2}{|c|}{0.9355} & -6.45 & 0.9657 & -3.43 \\
\hline \multicolumn{13}{|c|}{ Pearson correlation coefficients } \\
\hline$H I_{t}(3)$ & $H I_{t}(3)$ & $H I_{t}(6)$ & M2 & M3 & $N I_{t}$ & $H I_{t}(3)$ & $H I_{t}(6)$ & WIG & $H I_{t}(3)$ & $H I_{t}(6)$ & & WIG \\
\hline M2 & 1 & 0.9368 & $H I_{t}(3)$ & 0.9991 & M2 & 0.9216 & 0.9497 & M2 & -0.7142 & -0.8024 & $N I_{t}$ & -0.6692 \\
\hline M3 & 1 & 0.9205 & $H I_{t}(6)$ & 0.7422 & M3 & .9299 & 0.7476 & M3 & -0.6978 & -0.5414 & & \\
\hline
\end{tabular}

SOURCE: OWN ELABORATION.

Comparing annual indexes estimated using direct and indirect approaches we notice that the indexes calculated with the former approach are less influenced by the model specification than indexes calculated with the hedonic quality adjustment. It is made clear by comparing Pearson coefficients, which show a very strong (0.999) correlation between indexes directly obtained from the models M1 and M2, and a much weaker correlation (0.742) using the indirect approach. However, total returns in the entire period under study and average annual returns obtained via both methods are very similar. 
Analyzing Pearson coefficients (Table 6), we see that annual indexes obtained by direct and indirect methods are strongly correlated: the value of the coefficient is 0.937 for the model M2 and 0.92 for M3. Examining the similarities between hedonic and naive indexes we also see that when using the direct method there are strong correlations $(0.922$ for M2 and 0.93 for M3) between both types of index, whereas with the indirect methodology there is a strong correlation (0.95) between the naïve index and the hedonic index calculated by model M2 but a much weaker $(0.742)$ correlation with model M3.

Throughout the period under study, all hedonic indexes calculate smaller losses than the Warsaw Stock Exchange Index WIG. This is not the case, however, for the naive art index since it shows higher losses than those observed in the Polish capital market. The WIG fell dramatically in 2008 and the effects of the crisis were felt in the art market a year later. The Polish paintings market is negatively correlated with the equity market. The strength of the correlation between the stock market index and all estimated art indexes ranged from -0.541 to -0.802

\section{Conclusions}

Collecting art seems to be an attractive investment strategy and fine art is an alternative asset class with a proven track record. The global art market has been growing over at least the last ten years. The emerging markets in China, Russia and India among others have been rapidly developing and represent an ever more significant part of this market.

Art price indexes describe the financial performance of art and are used to compare returns from different asset classes. This paper examines the characteristic features of art as an investment and the major problems with estimating art indexes. The empirical part of the research consists of estimating hedonic art price indexes for selected Polish painters.

To construct an art price index, we used data from auctions held in Poland between 2007 and 2013. As a great variety of works are traded, we selected a sample of paintings (1710 paintings) by 17 Polish artists whose artworks are often traded at auctions. We do not claim that this selection is representative of the entire paintings market in Poland, as we only used data from auctions in order to ensure transparency and to reflect the structure of the Polish art market, and we set a minimum value of $€ 250$ in order to consider a painting as a piece of art. We applied the hedonic regression method, estimating art price indexes via the direct and indirect approach. We found that indexes estimated using the direct method are less sensitive to the hedonic model specification, and that there is a negative correlation between art and the equity market in Poland. 


\section{References}

Anderson, R.C. (1974). Paintings as an Investment, Economic Inquiry, 12(1), pp. 13-26.

Antczak, J. (2014). Construction of the Art Index on the Basis of Data from Polish Auctions, Master Thesis prepared under supervision of D. Witkowska, Warsaw University of Life Sciences, Warsaw (in Polish).

Ashenfelter, O. and Graddy, K. (2003). Auctions and the Price of Art, Journal of Economic Literature, 41(3), pp. 763-788

Ashenfelter, O. and Graddy, K. (2006). Art Auctions, in Ginsburgh, V. and Throsby, D. (eds.), Handbook of the Economics of Arts and Culture, Elsevier, North Holland, Amsterdam, pp. 909-945.

Białynicka Birula, J. (2009). Art market in Poland, Report for The Ministry of Culture and National Heritage in Poland (in Polish), http://www.kongreskultury.pl/library/File/RaportRynekSzt/rynek_dziel_sztuki_raport_w.pelna \%281\%29.pdf (accessed 31.10.2014). $\square$

Campbell, R.A.J. (2004). The Art of Portfolio Diversification, LIFE / Maastricht University Working Paper, http:// www.fdewb.unimaas.nl/finance/faculty/Campbell/images/Art\%20Investment.pdf (accessed 01. 07.2008).

Campbell, R.A.J. (2008). Art as a Financial Investment, The Journal of Alternative Investments, 10(4), pp. 64-81.

Candela, G. and Scorcu, A.E. (1997). A Price index for Art Market Auctions. An Application to the Italian Market of Modern and Contemporary Oil Paintings, Journal of Cultural Economics, 21, pp. 175-196.

Candela, G., Figini, P. and Scorcu, A.E. (2004).Price indices for artists - A proposal, Journal of Cultural Economics, 28(4), pp. 285-302.

Chanel, O, Gerard-Varet, L.A. and Ginsburgh, V. (1996). The Relevance of Hedonic Price Indices, Journal of Cultural Economics, 20(1), pp. 1-24.

Deloitte (2013). Rynek sztuki. Sztuka rynku. http://www.deloitte.com/assets/DcomPoland/Local\%20Assets/ Documents/Raporty,\%20badania,\%20rankingi/pl_Art\&Banking_PL.pdf (last accessed 12.11.2013).

Edwards, S. (2004). The economics of Latin American art: creativity patterns and rates of return, Economía, 4(2), pp. 1-35.

Frey, B.S. and Cueni, R. (2013). Why invest in art?, The Economist's Voice, 10(1), pp. 1-6.

Frey, B.S. and Eichenberger, R. (1995). On the rate of return in the art market: Survey and evaluation, European Economic Review, 39, pp. 528-537.

Frey, B.S. and Pommerehne, W.W. (1988). Is Art Such a Good Investment?, The Public Interest, 91, pp. 79-86.

Frey, B.S. and Pommerehne, W.W. (1989a). Art Investment: An Empirical Inquiry, Southern Economic Journal, 56(2), pp. 396-409.

Frey, B.S. and Pommerehne, W.W. (1989b). Muses and Markets. Explorations in the Economics of the Arts, Basil Blackwell, Cambridge, MA.

Gajewski, M. and Potocki, T. (2013). Skate's Focus: Poland's Art Market The Rising Star of Central Europe, report created by Skate's Art Market Research, Art \& Business Magazine S.A., Skate's, LLC, New York, USA. 
http://www.skatesart.files.wordpress.com/2013/03/skates-focus-polands-art-market.pdf (last accessed 29.01.2014). $\square$

Ginsburgh, V., Mei, J. and Moses, M. (2006). The Computation of Prices Indices, in Ginsburgh,V.A. and Throsby, D. (Eds.), Handbook of the Economics of Art and Culture, 1(27), pp. 947-979, Elsevier North Holland, Amsterdam.

Ginsburgh, V. and Schwed, N. (1992). Price Trends for Old Masters' Drawings: 1980-1991, The Art Newspaper, 9209, Universite Libre de Bruxelles - C.E.M.E. http://www.ecares.org/ecare/personal/ginsburgh/papers/077. drawings.pdf (accessed 03.02.2014).

Goetzmann, W.N., Renneboog, L. and Spaenjers, C. (2011). Art and money, American Economic Review, 101, pp. 222-226.

Higgs, H. (2012). Australian Art Market Prices during the Global Financial Crisis and two earlier decades, Australian Economic Papers, 51(4), pp. 189-209.

Higgs, H. and Worthington, A. (2005). Financial Returns and PriceDeterminants in the Australian Art Market, 19732003, Economic Record, 81(253), pp. 113-123.

Hsieh, S., Lee, J. and Tzeng, L.Y. (2010). Art as an Investment: Empirical Study of Asian Contemporary and Chinese 20th Century Modern Art, International Conference on Finance Department of Finance, National Taiwan University, December 10-11, 2010, discussion paper. http://www.fin.ntu.edu.tw/ conference/conference2010/proceedings/ proceeding/11/11-1(A40).pdf (accessed 7.11.2013). $\square$

- Jurevičienè, D. and Savičenko, J. (2012). Art investment for portfolio diversification, Intellectual Economics, 2(14), pp. 41-56.

Kompa, K. and Witkowska, D. (2013). Art Price Index. Preliminary Investigation for Selected Polish Painters, Zarzqdzanie i Finanse, 11(3), Part 2, pp. 33-50 (in Polish).

Kraeussl, R. and van Elsland, N. (2008). Constructing the True Art Market Index - A Novel 2-Step Hedonic Approach and its Application to the German Art Market, CFS Working Paper No. 2008/11, Center for Financial Studies Frankfurt University, Frankfurt.

Kraeussl, R. and Logher, R. (2010). Emerging Art Markets, Emerging Markets Review, 11(4), pp. 301-318.

Kraeussl, R. and Wiehenkamp, Ch. (2012). A Call on Art Investments, Review of Derivatives Research, 15(1), pp. 1-23.

Landes, W.M. (2000). Winning the Art Lottery: The Economic Returns to the Ganz Collection, John M. Olin Law and Economics Working Paper No. 76, Second series, The Law School, University of Chicago, Chicago.

Locatelli-Biey, M. and Zanola, R. (2002). The Sculpture Market: An Adjacent Year Regression Index, Journal of Cultural Economics, 26 (1), pp. 65-78.

Lucińska, A. (2012). The Careers of Artists And Prices of Paintings on Polish Art Market, in Zarzecki, D. (ed.), Finanse, Rynki Finansowe, Ubezpieczenia, 51, Zeszyty Naukowe Uniwersytetu Szczecińskiego, pp. 715-725 (in Polish).

Makselienè, S. (2007). Investing in art: whether it is time? [Investavimas į meną: ar jaulaikas?]. Retrieved from http://old.spekuliantai.lt/page.php?id=325 $\square$

Markley, K. (2014). Q4 Global Auction Report and Year in Review. http://news.artnet.com/market/q4-global-auctionreport-and-year-in-review-45544 (accessed 30.10.2014). 
McAndrew, C. (2013). TEFAF Art market report 2013 . The global art market, with a focus on China and Brazil, The European Fine Art Foundation, TEFAF Maastricht.

Mei, J. and Moses, M. (2002). Art as an Investment and the Underperformance of Masterpieces, American Economic Review, 92(5), pp. 1656-1668.

Mei, J. and Moses, M. (2005). Vested Interest and Biased Price Estimates: Evidence from an Auction Market, The Journal of Finance, 60(5), pp. 2409-2435.

Mok, H.M.K., Ko, V.W.K., Woo, S.S.M. and Kwok, K.Y.S. (1993). Modern ChinesePaintings: An Investment Alternative, Southern Economic Journal, 59(4), pp. 808-816.

Nesheim, L. (2006). Hedonic Price Functions, CEMMAP, London.

Pesando, J.E. (1993). Art as an Investment: The Market for Modern Prints, American Economic Review, 83, pp. 1075-1089.

Pesando, J.E. and Shum, P.M. (1999). The Returns to Picasso's Prints and to Traditional Financial Assets, 1977 to 1996, Journal of Cultural Economics, 23(3), pp. 183-192.

- Potocki,T. (2012). Sztuka inwestowania w sztukę, http://www.artbiznes.pl/inex.php/sztuka-inwestowania-w-sztukę (07.08.2014).

Renneboog, L. and van Houtte, T. (2002). The monetary appreciation of paintings: From realism to Magritte, Cambridge Journal of Economics, 26, pp. 331-357.

Renneboog, L. and Spaenjers, C. (2009). Buying Beauty on Prices and Returns in the Art Market, Discussion Paper 2009-15, Tilburg University, Tilburg Law and Economic Centre.

Renneboog, L. and Spaenjers, C. (2013). Buying Beauty on Prices and Returns in the Art Market, Management Science, 59(1), pp. 36-53.

Sommer, K. (2013). The Art of Investing in Art. http://www.jpmorgan.com/pages/jpmorgan/is/thought/magazine/ 3Q2013/art (accessed 08.09.2014).

Stein, J.P. (1977). The monetary appreciation of paintings, Journal of Political Economy, 85, pp. 1021-1035.

Tully, K. (2014). How Useful Are Art Indices?, Forbes, http://www.forbes.com/sites/kathryntully/2014/09/05/howuseful-are-art-indices/ (accessed 31.10.2014).

Witkowska, D. (2014). An Application of Hedonic Regression to Evaluate Prices of Polish Paintings, International Advances in Economic Research, 20(3), pp. 281-293.

Worthington, A.C. and Higgs, H. (2003). Art as an Investment: Short and Long-Term Comovements in Major Paintings Markets, Empirical Economics, 28, pp. 649-668.

Worthington, A.C. Higgs, H., 2004. Art as an Investment: Risk, Return and Portfolio Diversification in Major Painting Markets, Accounting and Finance, 44, pp. 257-271. 
